\title{
Difficult beginning? The early years of the Royal Academy of Arts in London
}

In his first discourse at the official opening of the Royal Academy of Arts in London (RA) on January 2nd 1769, Joshua Reynolds (1723-1792) proudly declared the institution open. Underneath the rhetorical veneer of the first president's official celebration, however, lay mixed feelings - those of an artist who revelled in his accomplishment while lamenting the amount of time the process had taken:

"An Academy, in which the Polite Arts may be regularly cultivated, is at last opened among us by Royal Munificence. This must appear an event in the highest degree interesting, not only to the Artist, but to the whole nation.

It is indeed difficult to give any other reason, why an empire like that of BRITAIN should so long have wanted an ornament so suitable to its greatness [...] and I can now congratulate you, Gentlemen, on the accomplishment of your long and ardent wishes" (Reynolds 79-80, emphasis added).

It had, in fact, taken so long to establish the RA that neither Reynolds nor any one of the thirty-three founding members in the audience had been involved in the creation of the first private academy, the Academy of St Luke, which had been opened by Godfrey Kneller (16461723 ) in 1711. None of them had been able to attend the classes given by James Thornhill (1676-1734) at his Free Academy in the 1720s, nor to follow the teachings provided by Louis Chéron (1655-1725) and John Vanderbank (1694-1739) at the first Academy of St Martin's Lane, between 1720 and 1725. However, all of them knew of the Academy of St Martin's Lane, created by William Hogarth (1697-1764) in 1735. For thirty-three years, most artists who were active in London - British or otherwise - had met there; they had attended life classes, engaged in aesthetic debates and designed collective solutions to promote British contemporary art. For twenty years, the members of the Academy of St Martin's Lane had been drawing up plans and projects in order to transform their private academy into a royal institution. Finally, on December 10th 1768, King George III signed the RA's 'Instrument of Foundation' (RAA/IF), thus putting an end to this exceptionally long academic movement.

Joshua Reynolds's expression of pride and joy mingled with relief was probably shared by his fellow academicians, who were aware that academies of art had existed for centuries on the continent and that the RA in London was amongst the last of those created in Europe. Moreover, over the ten years preceding the foundation of the RA, there had been a division in artistic community. In 1760, when diverging views had emerged regarding the organisation of public exhibitions, the members of the St Martin's Lane Academy had split into two groups: 'Members of the Free Society of Artists' (FSA) advocated free admission whereas those of the 'Society of Artists of Great Britain' (SAGB) insisted on charging an entrance fee. Both societies went on to organise annual spring exhibitions on their own terms, but the most prominent artists gathered in the latter group, which, by consequence, became the leading artists' society. Its superiority was considerably reinforced when the king granted it the privilege of being incorporated by Royal Charter on January 26th 1765. Changing its name to the 'Incorporated Society of Artists of Great Britain' (ISAGB), it spearheaded the project of a public academy. The establishment of such an institution seemed within reach and it probably could have been founded as early as 1767 , had not the Society been torn apart by internal jealousies (Hargraves 63-88). As a matter of fact, choices made by the Hanging Committee had come under renewed criticism by a group of talented young artists who challenged the authority of Directors. Although their discontent must be considered within the context of the wider reform movement of British political institutions in the $1760 \mathrm{~s}$, it was deeply rooted in a 
generational divide, and culminated in the defeat of the directors in the annual election held in October 1768: the President Francis Hayman (1708-1776) was replaced by John Joshua Kirby (1716-1774), and Richard Paton (1717-1791) became vice-president in place of Edward Penny (1714-1791). Following this result, the most senior artists resigned; led by William Chambers (1723-1796), they went on to petition the king and they managed to obtain his royal patronage and protection before their opponents who were led by Kirby. The RA did not, therefore, emerge as a collaborative venture of the ISAGB but was clearly established by the Society's former Directors (and their followers) at the expense of their challengers.

The early days, months and even years, of the RA were, consequently, uncertain and difficult times - all the more so since, immediately after its foundation, the king refused to accede to John Joshua Kirby's request to merge the remnant ISAGB into the newly-created RA in the name of reconciliation (Hargraves 93-95). As stated in Article I of the 'Instrument of Foundation', one of the defining principles of the RA was its numerus clausus; and the king's persistent support for the idea of a numerically limited elite formalised the distinction between academicians and non-academicians inside the emerging artistic field, thus bringing a long era of comprehensive organisation of the artistic community in London to a close. An explicit reference to this acute crisis, or to the resentment felt by those who had been excluded from the RA, is nowhere to be found in Joshua Reynolds's discourse. He cloaks months of internal strife with a vague allusion to "the numberless and ineffectual consultations which I have had with many in this assembly to form plans and concert schemes for an Academy" (Reynolds 80), and in doing so, he purely and simply ignores the claims of his former colleagues. Following their President's example, most royal academicians refused to engage in the debate regarding their legitimacy and rule, which raged for some years after 1768 . Whereas members of the ISAGB published pamphlets to denounce the conditions in which the RA had been created, the academicians whose names were specified never deigned to respond (See Thompson et al. and Strange).

While royal academicians turned a blind eye to their rivals' claims and criticisms, the fracture within the artistic community appeared in the London press, more specifically in the advertisement of public art exhibitions. Despite the dejection and disappointment that could be felt among the members of the ISAGB, and to a much lesser extent among those of the FSA in the aftermath of 1768 , the two societies that had been shaping the London artistic community since 1760 maintained their primary function, i.e. showcasing contemporary British artistic production. They therefore continued to organise their public exhibitions in the spring, but had to deal with a newcomer. In accordance with Article XVII of the 'Instrument of Foundation', royal academicians built upon the experience of the London artistic community and adopted what had become a defining feature of London cultural life - an annual exhibition which was designed not only as a central event, but as the key to the survival and financial independence of the new institution. Thus, from 1769 until 1783, when the FSA ceased to exist, there were potentially three public art exhibitions to be advertised in London each year. Then, from 1783 until the demise of the ISAGB, there were two. What these advertisements tell us is not the sole chronicle of the death foretold of the RA's rivals. Although those texts might have only been a couple of lines long, they were aimed at notifying the London public about exhibitions. They were supposed to attract the readers' attention, and to encourage them to come and pay to see contemporary art works; with three exhibitions to choose from, they were designed so as to help the public make up their minds. Since the early decades of the eighteenth century, London periodicals had been 'advertisers' and, as such, would circulate various pieces of commercial information, as well as promoting works of art. Indeed, as has been amply illustrated by David Solkin, Ann Bermingham and 
John Brewer, the emergence of an art market in London in the first half of the eighteenth century introduced a new form of consumer behaviour, which affected the production as well as the reception of artworks.

Since very few official sources exist on how academicians dealt with the accusations that were thrown at them, these advertisements are worth studying. They not only allow us to trace the continuing struggle between royal academicians and their opponents, but also bring the aims of artists from both sides into the public sphere. The layout of pages on which these advertisements were published, the typefaces and the wording used, provide invaluable information about the image that artists wished to present to the public, whose approval had been anxiously sought ever since the exhibitions were first organised.

\section{Three 'Societies' on a Par?}

In the spring of 1769 , several London newspapers published three consecutive advertisements in the same column, as can be seen from the issue of The Public Advertiser dated April $26^{\text {th }}$ of that year (no issue number on the front page):

Royal Academy, Pall-mall, April 21, 1769.

THE EXHIBITION will open on WED NESDAY next, the 26th Instant, at NINE o' clock.

Admittance One Shilling each Person. The Catalogue gratis.

F.M. NEWTON, Sec.

THE Free Society of ARTISTS associated for the Relief of their distressed Brethren, their Widows and Children, give notice that their EXHIBITION for the present Year will open on the 28th Instant, and is removed from the Room, late Mr. Dalton's, to Mr. Christie's New Great Room next Cumberland House, Pall-mall, where it will be continued for the future.

By Order of the SOCIETY, J. FURMAN, Sec.

ROYAL INCORPORATED SOCIETY of ARTISTS of GREAT BRITAIN.

THE President and Directors give Notice That their Annual Exhibition (being the Tenth) will be early in May next, at their Room in Spring Garden, Charing-Cross. N.B. The Artists are desired to send their several Performances to the Room above mentioned on Tuesday 25th, or before Twelve o'clock on Wednesday 26th of April Inst. after which Time no Performance can be admitted.

JAMES PAINE, Secretary. 
Note, None but original Performances will be

received.

London art-lovers therefore had three exhibitions to choose from and neither the relative sizes of letters nor the general layout of advertisements - which I have tried to reproduce here could help them rank the events or give preference to one over the others. However, each organizing body provided specific information in order to assist exhibition-goers in making their choice. The FSA, for instance, used its full name The Free Society of Artists associated for the Relief of their distressed Brethren, their Widows and Children in order to underline its superior disinterestedness. Indeed, since 1761, both the FSA and the ISAGB had been devoting part of the revenue they drew from their exhibitions to the setting up of mutual funds for artists. The RA had undertaken the same commitment in Article XVII of its 'Instrument of Foundation'. However, the FSA did so without asking visitors to pay an entrance fee, and instead took it solely from the takings from the sale of catalogues, which drastically limited the scope of its action and even threatened its very existence. The ISAGB advertisement does not mention an entrance fee, perhaps because the art-going public was all too familiar with this defining feature of the Society. The lack of reference to the entrance fee might also take on particular importance, considering that the RA advertisement clearly states its charge for entry. Indeed, not only had the RA taken up both societies on the organisation of a spring exhibition - so that all three events were to occur at the same time, at the height of the 'London season' - but it had also adopted the ISAGB terms of entry (for example, the entrance fee of one shilling, with complimentary catalogue). On this point, among others, the founding members of the RA had naturally drawn on their experience as former SAGB and ISAGB fellows when defining the RA's mode of operation. Because of the British parliamentary monarchy's reduced scope for patronage, they had to introduce an entrance fee, as they knew it was the surest way to achieve financial independence. Although the introduction of an admission charge was necessary, academicians were concerned that it might tarnish their image and this issue was so urgent that it was among the first that the RA Council chose to address. In January 1769, it resolved that 'a Preface be prefixed to the Catalogue to apologise for our taking Money' (RAA/CMI, 12). A month later they approved the actual apology:

"As the present Exhibition is a part of the Institution of an Academy supported by Royal Munificence, the Public may naturally expect the liberty of being admitted without any Expense.

The Academicians therefore think it necessary to declare that this was very much their desire but that they have not been able to suggest any other means than that of receiving Money for Admittance to prevent the Room from being filled by improper Persons to the entire exclusion of those for whom the Exhibition is apparently intended" (RAA/CMI, 15).

This text reflects the arguments which had already been put forward by the SAGB in its 1762 Catalogue of the Pictures, Sculptures, Models, Drawings, Prints \&c. (preface, v):

"Of the price put upon this Exhibition some account may be demanded. Whoever sets his work to be shewn, naturally desires a multitude of spectators, but his desire defeats its own end, when spectators assemble in such numbers as to obstruct one another. Tho' we are far from wishing to diminish the pleasures or depreciate the sentiments of any class of the community, we know however, what every one knows, that all cannot be judges or purchasers of works of art; yet we have already found by experience, that all are desirous to see an Exhibition. When the terms of admission were low, our room was throng'd with such 
multitudes as made access dangerous, and frightened away those, whose approbation was most desired."

The similarities between the two texts are striking but not surprising, since Joshua Reynolds had asked Samuel Johnson to draft the preface to the SAGB catalogue in 1762 (Edwards, Introduction, xviii). The recapitulation of the arguments after seven years attests to the fact that academicians were still confronted with the dilemma they had faced as fellows of the SAGB. They were still torn between economic realism and liberal ambitions, between what Pierre Bourdieu identified as the two antagonistic logics of the artistic field (Bourdieu 211). On the one hand, artists had to sell their works and, on the other, they had to endorse disinterestedness as their guiding principle. Even though the 1769 apology appears as a watered-down version of the 1762 preface, which graphically portrayed an ignorant mob facing off an economic and intellectual elite, British academicians had yet to demonstrate their liberal status. More than any other continental academicians, they had to vindicate their liberal status precisely because they did not receive a pension from the king and because they had to organise exhibitions in order to support their institution.

While their former colleagues from the ISAGB did not seem ready to acknowledge their new distinction promptly, academicians did not engage in any debate with them. In keeping with their typical aloofness, the advertisement for their first exhibition is very brief and very vague. Only the word 'exhibition', written in large, bold, capital letters stands out in their message, expressing their proud confidence in their ability to attract visitors with this word alone. On the other hand, the ISAGB published a long advertisement and all the additional information it includes is aimed at distinguishing it from its competitors. The final note about the necessary originality of the exhibits is a forceful reminder of the ISAGB's commitment to the value of artistic invention, and thus to the elevated idea that its members had of artistic practice. The statement aimed both to differentiate the ISAGB from the FSA, which did not have the same requirements and agreed to exhibit copies, and to identify it with the RA. Indeed, in this 'note' - which is but a mere footnote - the ISAGB speaks the language of academic distinction when declaring its dedication to 'intellectual' (i.e. not mechanical) endeavours in painting. The ISAGB had been anxious to support a dignified and liberal status for artists since 1765, but, with the foundation of the RA, there was now an official body dedicated to the 'polite arts' and to the encouragement of 'the higher Arts of Design' (Reynolds 79). Moreover, in a previous advertisement, published in The Public Advertiser on April 1st, 1769 (issue 10741), the RA had already announced its exhibition rules, including the following: "N.B. No Copies, nor any Pictures, \&c. without Frames, will be admitted."

The blurring of identities is even more confusing with the addition of the adjective 'royal' before the name of the ISAGB. Although a Royal Charter had indeed been granted to the society four years earlier, it had never been referred to as the Royal ISAGB. The sudden change to its name brought the crucial issue of the anteriority of royal protection to the fore. In the petition they had presented to the king in December 1768, the members of the ISAGB had already argued that the RA founding-members' initiative had been in breach of the rights guaranteed by the Royal Charter (Hargraves 94). Drawing on the terms of the solemn oath of loyalty the society's members had been taking since February 1765, they had denounced the foundation of the RA on grounds of disloyalty and unconstitutionality. Their attempt proved unsuccessful, however, since the king could not fail to see the questioning of his authority underlying their claim. Thus, in the following spring when the RA was about to open its first exhibition, the ISAGB members were left to remind the public that King George III had given them priority in 1765 , and that they had been consistently offering art exhibitions to the public 
for ten years. Interestingly, they also used the adjective 'royal' on the front page of their 1769 catalogue. Whereas it had taken them two years to change their name from the SAGB to the ISAGB on their catalogue cover, the pointed emphasis on their link with the monarchy in 1769 was clearly aimed at undermining the RA's position.

It is a fact that after the failure of the December petition, the president of the ISAGB, John Joshua Kirby, for fear of displeasing the king, had opted for an emulation strategy. After all, the Royal Academy had been defined in the preamble to the 'Instrument of Foundation' as a 'Society for promoting the Arts of Design' and his was also an artistic society distinguished by royal favour with a national purpose embedded in its very name. Yet, in February 1765, shortly after it had been granted its Royal Charter, the ISAGB had only set itself a narrow professional purpose - to "promote the Honour and Interest of the Society of Artists of GreatBritain' (RAA, SA/10). Notably, academicians had not set themselves any broader goal in the 'Instrument of Foundation' either. Nonetheless they only had to wait for a few days until their President opened his first discourse with the momentous statement quoted above, in which he refers not only to the 'national', but also to what might be called the 'imperial' dimensions of the RA.

\section{The RA as the official liberal artistic body}

On May, 1st 1770, three consecutive advertisements were again published in The Public Advertiser (issue 11053), announcing the opening of the three exhibitions:

\section{Royal Academy, Pall-mall}

THE EXHIBITION of the ROYAL ACADEMY is now open, and will continue every Day (Sundays excepted) from Eight o'Clock in the Morning till Seven in the Evening.

Admittance One Shilling. The Catalogue gratis.

F. M. NEWTON, Sec.

SPRING GARDEN, Charing Cross.

THE PRESIDENT and DIRECTORS of the Royal Incorporated Society of ARTISTS of Great Britain give Notice, that their Annual EXHIBITION (being the eleventh) will open this Day at Eight o'Clock in the Morning, and continue till Seven in the Evening.

W. WOLLETT, Sec.

Admittance One Shilling. The Catalogue gratis.

\section{EXHIBITION.}

The SOCIETY OF ARTISTS associated for the relief of their distressed Brethren, their Widows and Children, give Notice, that their annual Exhibition at Mr. CHRISTIE's 
Great Room next Cumberland House in

Pall-mall, will open This Day at Twelve, and continue every Day till further Notice.

J. FURMAN, Sec.

Admittance One Shilling. The Catalogue gratis.

These provided readers with more or less the same essential information. The major difference between them and the previous advertisements is that they all referred to an admission charge and even to an identical entrance fee fixed at one shilling, with a complimentary catalogue. As of 1770, therefore, all three artists' societies operated along the lines defined by the ISAGB, and were all funded by the sales of admission tickets to their annual exhibition. This evolution confirmed the validity of the original approach adopted by the members of the SAGB, but it also testified to the increasing levels of competition in the artistic arena. Far from being pure and perfect, this competition was overtly flawed, because the King helped the RA balance its books (Hodgson and Eaton 29). Even though George III had been granting the ISAGB occasional donations, the financial support he gave to the RA over its first twelve years of existence, despite its modesty, allowed academicians to enjoy a unique form of financial security. By contrast, economic hardship led to the resignation of John Joshua Kirby who was replaced by James Paine (1717-1789), as President of the ISAGB, in June 1770.

Very similar advertisements were published in 1771 and significant changes were to be found only the following year. In 1772, members of the ISAGB placed all their hopes in a new exhibition venue, specially designed by James Paine, which had been erected on the Strand in one year. In their advertisement published in The Daily Advertiser on April 30th 1772 (issue 12902), which was once again placed next to that of the FSA and the RA, they naturally informed the public that their exhibition would take place in this new room, and that a concert would be given on the opening day, May 8th. Despite the grand ceremony, the magnificent new exhibition room and the number of good-quality history paintings presented by the ISAGB, there were fewer visitors (Hargraves 117-128). On the contrary, admissions at the RA exhibition had almost doubled and, most importantly, the RA had managed to establish itself as a temple to the liberal arts. Indeed, less than a month before the grand opening of the ISAGB exhibition, the RA had announced in The Daily Advertiser, on April, 11th 1772 (issue 12886), the new restrictions it imposed upon exhibitors: "Note. No Copies Whatever, nor any Imitations of Painting in Needlework, Artificial Flowers, Shellwork, or any Thing of that Kind will be admitted, nor any Pictures \&c. without Frames". Such handcrafted works had featured in all London art exhibitions since 1760 and had sometimes even earned their authors respect and recognition, such as in the case of Mary Delany (1700-1788), famed for her almost one thousand botanical collages (see Laird and Weisberg-Roberts). Yet, in 1770, the Council of the RA had decided to exclude such productions and "Resolved That no NeedleWork, artificial Flowers, cut Papers, Shell-work, or any such Baubles shall be admitted into the Exhibition" (RAA/CM I, 75 and RAA/CM I, 76). In the public advertisement the word 'bauble' was replaced by the less pointed expression 'or any thing of that kind', but it nevertheless indicates the contempt academicians held toward for these productions. Both texts asserted that there was no place for handicrafts at the RA, whereas both the ISAGB and the FSA exhibited them in high numbers. With this publication, academicians made a symbolic but nonetheless brutal move, establishing themselves in a liberal class of their own, above other artists. This statement was congruent with Article I of the 'Instrument of 
Foundation' in which membership of the RA was restricted to practitioners of the fine arts (painting, sculpture and architecture). Even though RA exhibitions showcased the skills of both academicians and non-academicians, they were not open to those who did not practise the liberal arts.

This restriction went against the grain of what had been common practice for both artists' societies since the first public art exhibition had been held. Indeed, since 1760, both the FSA and the ISAGB had opened their doors to all creative endeavours without discrimination. The encouragement given by the first London art exhibitions to amateur artists is an area which still needs to be assessed and analysed, and which can be grasped by consulting exhibition catalogues. Such comprehensiveness is obviously to be related to a pre-academic, preprofessional notion of art, as well as to the specific obligation British artists had felt since the early decades of the eighteenth century to provide numerical evidence of their existence, thus dismissing the French authors who had refuted the reality of an 'English School'. It is highly revealing that the first modern attempt at vindicating the existence of an 'English School' was made by poet Bainbrigg Buckeridge (1668-1733) through the compilation of an alphabetical list of one hundred artists, which was published as an appendix to the English edition of Roger de Piles's works (see The Art of Painting 398-480). Tellingly, at a time when the RA presented itself as a liberal stronghold, both the FSA and the ISAGB carried on exhibiting amateur works. Both their 1772 catalogues show that oil paintings were outnumbered by works in watercolours, crayons, chalk, pencil, and ink as well as by engravings, often reproducing paintings by academicians. They also include needlework and shellwork, such as that disparaged in the RA advertisement, as well as compositions (portraits, landscapes, still lifes and even mythological scenes) made of human hair, which were very popular at the time (see Catalogue of the FSA 7, 8, 9, 14 and Catalogue of the ISAGB 8, 15, 19, 22, 27, 30). Even though, in 1772, the ISAGB catalogue presented 411 entries (compared to 315 for the RA's), many works fell under the categories described by academicians as 'baubles', i.e. as trinkets, or pieces of trifling value.

The separation of the three visual arts (painting, sculpture and architecture) from crafts had been one of the founding pillars of the new liberal identity of artists since the Renaissance and the institutional expression of this new value system was the academy (see Kristeller). It is therefore not surprising that royal academicians in London relied on the distinction between liberal and mechanical arts in order to boast their social and intellectual prestige. Unsurprisingly, they reaped the benefits of their strategy of social distinction, and managed to attract the best talent from the ISAGB (Hargraves 140). Despite its new exhibition venue, the ISAGB attendance figures continued to fall, causing its revenues to dwindle and its president to resign once again. Until 1780, the three exhibitions continued to be advertised next to one another in the London press. After the removal of the RA to Somerset House, however, which Joshua Reynolds presented in his ninth discourse as the cradle of the English School, both artists' societies were left with nothing. The last FSA exhibition took place in 1783 while the ISAGB managed - albeit with difficulty - to set up three exhibitions before ceasing its activities in 1791 .

David Solkin was one of the first scholars to study the rift created in London's artistic community following the founding of the RA, considering it from a political and economic perspective and placing the artistic event in a much wider social framework (Solkin 260-276). Since then, scholars have tried to identify the similarities and differences between the British institution and its continental forerunners, while Matthew Hargraves's study documented how 
the RA was built on the ISAGB legacy. Many developments in Hargraves's historical account point at the very fine line that separated the ISAGB from the newly-created RA in 1768, and question the process which transformed it into an unbridgeable gap over the course of just a few years. At some point, he draws on both Nicholas Penny and Nicholas Savage to put forward the idea that the RA did nothing that the ISAGB could not? already do, and that the main (and vital) difference between the two was the validation of the RA's functions by the King (Hargraves 91). What this study of press adverts shows is that the royal nature of the academy was indeed challenged and that the argument revolved around the anteriority of royal recognition. When the ISAGB suddenly started referring to itself as the 'Royal ISAGB' in 1769, it tried to prevent the RA from retaining exclusive possession of an adjective from which both material and symbolic benefits could be derived. Meanwhile, as Holger Hoock has shown, academicians built on the royal patronage they enjoyed in order to appear as 'the king's artists', and to emphasize the national purpose and significance of their action. What these press advertisements also show is that the RA's legitimacy was not merely based in nationalist or patriotic discourses. If the adjective 'royal' linked it to the British monarchy, the noun 'academy' expanded its institutional roots beyond Britain to the renowned academies of Italy and France. From these advertisements, we read that the RA was predicated on traditional liberal academic values that had been used for centuries to delineate the status of an elite composed of artists. They therefore exemplify how the national and international symbols reinforced one another and strengthened the authority and rule of the RA.

Isabelle Baudino (ENS de Lyon, LIRE)

\section{List of works cited}

\section{Primary sources}

The Royal Academy Archives (RAA)

Council Minutes (CM)

Society of Artists Papers (SA)

A Catalogue of the Pictures, Sculptures, Models, Drawings, Prints \&c. Exhibited by the Society of Artists of Great Britain at the Great Room in Spring Gardens, Charing Cross. May the 7th, Anno 1762. Being the Third Year of their Exhibition. London: n.p., 1762.

A Catalogue of the Pictures, Sculptures, Designs in Architecture, Models, Drawings, Prints $\& c$. Exhibited at the Great Room in Spring-Gardens, Charing-Cross. May the First 1769. By the Royal-Incorporated Society of Artists of Great Britain. The Tenth Year of Exhibiting. London: Bunce, 1769.

A Catalogue of the Paintings, Sculptures, Designs in Architecture, Models, Drawings, Engravings, \&c. now Exhibiting by the Society of Artists, Associated for the Relief of Their Distressed Brethren, their Widows and Children, at Mr. Christie's New Great Room, next to Cumberland House, Pall-Mall. Being the Thirteenth Year of their Exhibition. London: Harrison, 1772.

A Catalogue of the Pictures, Sculptures, Models, Designs in Architecture, Drawings, Prints \&c. Exhibited at their New Room, Near Exeter-Exchange, Strand, May the Thirteenth, 1772, 
by the Society of Artists of Great Britain. The Thirteenth Year of Exhibiting. London: Bunce, 1772.

The Daily Advertiser

The Public Advertiser

The Art of Painting and the Lives of the Painters: containing, a Compleat Treatise of Painting, Designing and the Use of Prints: With Reflections on the Works of the Most Celebrated Painters, and of the Several Schools of Europe, as Well Ancient as Modern. Being the Newest and Most Perfect Work of the Kind Extant. Done from the French of Monsieur De Piles. To Which is Added, An Essay Towards an English-School, With the Lives and Characters of Above 100 Painters. London: Nutt, 1706.

Edwards, Edward. Anecdotes of Painters. London: Hansard, 1808.

Reynolds, Sir Joshua. Discourses. Edited by Pat Rogers. London: Penguin, 1992.

Strange, Robert. An Inquiry into the Rise and Establishment of the Royal Academy of Arts to Which is Prefxed a Letter to the Earl of Bute. London: Dilly, Robson and Walter, 1775.

Thompson,William, et al. (published anonymously). The Conduct of the Royal Academicians, While Members of the Incorporated Society of Artists of Great Britain, Viz. from the Year 1760, to Their Expulsion in the Year 1769. London: Dixwell, 1771.

\section{Secondary sources}

Bourdieu, Pierre. Les règles de l'art. Genèse et structure du champ littéraire. Paris : Seuil, 1992.

Bermingham, Ann and John Brewer. Eds. The Consumption of Culture 1600-1800: Image, Object, Text. London: Routledge, 1995.

Hargraves, Matthew. 'Candidates for Fame'. The Society of Artists of Great Britain 17601791. New Haven and London: Yale UP, 2005.

Hodgson, John E. and Frederick A. Eaton. The Royal Academy and its Members, 1768-1830. London: Murray, 1905.

Hoock, Holger. The King's Artists. The Royal Academy of Arts and the Politics of British Culture, 1760-1840. Oxford: Clarendon, 2003.

Kristeller, Paul Oskar. 'The Modern System of the Arts: A Study in the History of Aesthetics.' Part I, Journal of the History of Ideas 12.4 (1951) 496-527.

Laird, Mark and Alicia Weisberg-Roberts. Ed. Mrs Delany and Her Circle. New Haven and London: Yale UP, 2009.

Solkin, David. Painting for Money:? The Visual Arts and the Public Sphere in EighteenthCentury England.New Haven and London: Yale UP, 1992. 